\title{
O010. Migraine aura symptoms last for more than one hour in more than one quarter of patients: results from a prospective diary-aided study
}

\author{
Michele Viana ${ }^{1 *}$, Mattias Linde ${ }^{2,3}$, Grazia Sances$^{1}$, Natascia Ghiotto ${ }^{1}$, Elena Guaschino ${ }^{1}$, Marta Allena', \\ Giuseppe Nappi ${ }^{1}$, Peter J Goadsby ${ }^{4}$, Cristina Tassorelli ${ }^{1,5}$
}

From Abstracts from the 1st Joint ANIRCEF-SISC Congress

Rome, Italy. 29-31 October 2015

\section{Background}

As there are no biological markers, a detailed description of symptoms, particularly temporal characteristics, is crucial when diagnosing migraine aura. In ICHD-IIIbeta, migraine aura duration is considered normal when each symptom is no longer than one hour. A recent systematic review of the topic [1] did not find any article exclusively focusing on the duration of the aura. The pooled analysis of data from the literature on aura duration showed that visual symptoms lasting for more than one hour occurred in 6\%-10\% of patients, sensory symptoms in $14 \%-27 \%$ and dysphasic aura in $17 \%-60 \%$. Here we investigated the duration of aura symptoms, using a prospective diary-aided approach.

\section{Methods}

We recruited 176 consecutive patients affected by migraine with aura at the Headache Centres of Pavia and Trondheim. The study received approval by the local Ethics Committees. All patients signed an informed consent form. All the patients prospectively recorded the characteristics of three consecutive attacks in an ad hoc aura diary that included the time of onset and the end of each aura symptom and the headache.

\section{Results}

Fifty-four patients completed the study recording in a diary the characteristics of three consecutive auras $(n=162$ auras). Out of 162 auras that were evaluated, visual symptoms occurred in 159 (97\%), sensory symptoms in
$52(32 \%)$, and dysphasic symptoms in $18(11 \%)$. The cumulative number of aura symptoms recorded was therefore 229. The median duration of visual, sensory and dysphasic symptoms was 30,20 and 20 minutes, respectively. Visual symptoms lasted for more than one hour in $14 \%$ of auras $(n=158)$, sensory symptoms in $21 \%$ of auras $(\mathrm{n}=52)$, dysphasic symptoms in $17 \%$ of auras $(n=17)$. Twenty-six percent of patients had at least one aura out of three with one symptom lasting for more than one hour.

\section{Conclusions}

This is the first study specifically focused on temporal aspects of migraine with aura. We provide data to suggest that aura symptoms may last longer than one hour in a relevant proportion of auras or migraine with aura patients. These findings will contribute to a better phenotypical framing of migraine with aura and may be of help in the review process of the international classification of headache disorders.

Written informed consent to publication was obtained from the patient(s).

\section{Conflict of interest}

None.

\section{Acknowledgements}

This study was carried out in collaboration with UCADH (University Consortium for Adaptive Disorders and Head pain), University of Pavia, Italy. This work was supported by grants of the Italian Ministry of Health to RC 2013-2015.

\footnotetext{
* Correspondence: michele.viana@ymail.com

${ }^{1}$ Headache Science Centre, C. Mondino National Neurological Institute, Pavia, Italy

Full list of author information is available at the end of the article
} original work is properly cited. The Creative Commons Public Domain Dedication waiver (http://creativecommons.org/publicdomain/ zero/1.0/) applies to the data made available in this article, unless otherwise stated. 


\section{Authors' details}

'Headache Science Centre, C. Mondino National Neurological Institute, Pavia, Italy. ${ }^{2}$ Department of Neuroscience, Norwegian University of Science and Technology, Trondheim, Norway. ${ }^{3}$ Norwegian Advisory Unit on Headaches, St. Olavs University Hospital, Trondheim, Norway. ${ }^{4}$ Headache Group, NIHRWellcome Trust Clinical Research Facility, King's College, London, UK.

${ }^{5}$ Department of Brain and Behavioural Sciences, University of Pavia, Pavia, Italy.

Published: 28 September 2015

\section{Reference}

1. Viana M, Sprenger T, Andelova M, Goadsby PJ: The typical duration of migraine aura: A systematic review. Cephalalgia 2013, 33(7):483-90.

doi:10.1186/1129-2377-16-S1-A65

Cite this article as: Viana et al:: O010. Migraine aura symptoms last for more than one hour in more than one quarter of patients: results from a prospective diary-aided study. The Journal of Headache and Pain 2015 16(Suppl 1):A65.

\section{Submit your manuscript to a SpringerOpen ${ }^{\mathcal{O}}$ journal and benefit from:}

- Convenient online submission

- Rigorous peer review

- Immediate publication on acceptance

- Open access: articles freely available online

- High visibility within the field

- Retaining the copyright to your article

Submit your next manuscript at $\gg$ springeropen.com 